\title{
Changes in Macular Pigment Optical Density among Pseudophakic Patients following Intake of a Lutein-Containing Supplement
}

\author{
Rijo Hayashia Shimmin Hayashi ${ }^{a}$ b Shigeki Machida ${ }^{a}$ \\ aDepartment of Ophthalmology, Saitama Medical Center, Dokkyo Medical University, Koshigaya, Japan; bively Eye \\ Clinic, Soka, Japan
}

\section{Keywords}

Lutein - Macular pigment optical density · Pseudophakia ·

Clear intraocular lens · Gender differences

\begin{abstract}
Introduction: Cataract surgery has been reported as a longterm risk of reduced macular pigment optical density (MPOD). This study investigated changes in MPOD in pseudophakic patients after lutein supplementation. Methods: Fifty-seven patients who had no ocular diseases and underwent cataract surgery with concurrent implantation of clear intraocular lenses were included. MPOD was measured before lutein supplementation and every week during 6 weeks of supplementation. Two additional measurements were conducted after the end of supplementation. Results: Compared with baseline, MPOD was increased after 1 week of supplementation $(p<0.01)$ and remained elevated after cessation of supplementation. After 3 weeks of supplementation, MPOD in females was higher than that in males $(p<$ 0.05). Compared with patients at the highest quintile baseline MPOD, patients of both genders at the lowest quintile had significant increases after 6 weeks of supplementation $(p<0.05)$. Conclusion: MPOD increased after lutein supplementation in patients who had undergone cataract surgery.
\end{abstract}

karger@karger.com www.karger.com/ore

Karger!"
C 2021 The Author(s).

Published by S. Karger AG, Basel

This is an Open Access article licensed under the Creative Commons Attribution-NonCommercial-4.0 International License (CC BY-NC) (http://www.karger.com/Services/OpenAccessLicense), applicable to the online version of the article only. Usage and distribution for commercial purposes requires written permission.
With the same amount of lutein supplementation, MPOD increased more in patients with low MPOD at baseline; it also increased more in females than in males. Lutein supplementation is presumed to support increased MPOD, which can reduce the risk of age-related macular degeneration, especially in females with low MPOD.

(c) 2021 The Author(s).

Published by S. Karger AG, Basel

\section{Introduction}

Lutein, zeaxanthin, and their metabolite, mesozeaxanthin, are carotenoids concentrated in the retina, which are used to form macular pigments (MPs) known as xanthophylls. These xanthophylls protect photoreceptor outer segments and the retinal pigment epithelium via absorbance of blue light and quenching of reactive oxygen species [1]. Throughout the retina, lutein and zeaxanthin might also protect against age-related macular degeneration (AMD) by reducing oxidative stress [2-4] and inflammation [4-6]. The presence of lutein and zeaxanthin has also been shown to reduce lipofuscin [7-9], which is considered a precursor of AMD. Lower lutein and zeaxanthin levels have been found in the inner and medial regions of the retina in cadaver donors with AMD [10]. 
There is also epidemiological evidence to indicate that higher lutein and zeaxanthin levels in the diet or blood are protective against advanced AMD [11].

MP protects the retina from light damage [11-13]. In the fovea, MP can absorb $40-90 \%$ of short-wavelength light [14] that could otherwise damage the retina $[15,16]$. Patients with a confirmed family history of AMD have significantly lower MP optical density (MPOD) [17]. Reportedly, MPOD is significantly lower in AMD eyes [1820]. MPOD has also been associated with dietary and serum lutein and zeaxanthin [21-23]. Furthermore, MP concentrations are readily impacted by oral supplementation through both diet and vitamin intake $[24,25]$.

Aged lenses, which exhibit cataracts, are considered to be natural filters that decrease the transmittance of shortwavelength light, thereby reducing retinal phototoxicity [26]. Cataract surgery involves implantation of clear intraocular lenses (IOLs), which increases the transmittance of light at approximately $410 \mathrm{~nm}$ [27]; this enables visible spectrum and short-wavelength light to reach the retina and potentially cause retinal pigment epithelial cell damage [28]. Cataract surgery has been reported as a factor associated with risk of reduced MPOD [29, 30]. Demirel et al. [31] reported that MPOD values were lower in patients who had undergone cataract surgery than in age-matched patients with clear lenses. Furthermore, inverse correlations have been observed between the duration of the postoperative period and MPOD values, as well as between the duration of the postoperative period and increased incidence of AMD [32,33]. The possibilities of increases in MPOD [34] and retinal protection have been suggested with the implantation of blue lightfiltering IOLs which contain yellow chromophores and attenuate the transmission short-wavelength light as aged lenses [35, 36]. However, longer-term effects of blue lightfiltering IOLs on macular health or MPOD were inconclusive in the results of a meta-analysis [37]. It has been reported that MPOD positively correlated with oral intake of lutein from food and serum levels of lutein [38, 39]. Intake of lutein supplement is also a promising candidate for preventing the decreases in MPOD after cataract surgery.

Heterochromatic flicker photometry is a commonly used technique for measuring MPOD, based on the principle of matching the luminance of flickering blue and green lights. Yellow coloring in the optic pathway, such as that demonstrated by cataractous lenses and yellowtinted IOLs, absorbs blue light and may cause incorrect measurements. In this study, we examined patients who had undergone implantation of clear IOLs to investigate
Table 1. The composition of Ocuvite + Lutein $^{\circledR}$

\begin{tabular}{lc}
\hline Substance & Amount \\
\hline Lutein & $6.0 \mathrm{mg}$ \\
Vitamin C & $300.0 \mathrm{mg}$ \\
Vitamin E & $60.0 \mathrm{mg}$ \\
Vitamin $\mathrm{B}_{2}$ & $3.0 \mathrm{mg}$ \\
$\beta$-Carotene & $1,200.0 \mu \mathrm{g}$ \\
Niacin & $12.0 \mathrm{mg}$ \\
Zinc & $9.0 \mathrm{mg}$ \\
Selenium & $45.0 \mu \mathrm{g}$ \\
Copper & $0.6 \mathrm{mg}$ \\
Manganese & $1.5 \mathrm{mg}$ \\
\hline
\end{tabular}

the effects of lutein supplementation on changes in MPOD after cataract surgery. Gender differences were also investigated. This is the first investigation of MPOD in pseudophakic patients with clear IOLs.

\section{Materials and Methods}

Subjects

Patients who underwent bilateral cataract surgery at the Lively Eye Clinic from May 2016 to December 2016 and had postoperative visual acuity better than 1.0 in decimal scale measurements with the Landolt $\mathrm{C}$ chart were included in this study. Clear IOLs (TECNIS ${ }^{\circledR}$ Onepiece ZCB00; USA) were implanted in all patients. Informed consent was obtained from all patients for inclusion before they participated in the study, and the study was performed in accordance with the tenets of the Declaration of Helsinki. Approval was granted by the institutional Human Experimentation Committee in Dokkyo Medical University. Patients with ocular complications (e.g., uveitis and retinopathy) were excluded from this study, as were patients with systemic disease (including diabetes) and those taking other supplements.

Excluding patients with visual acuity worse than 1.0 after cataract surgery, patients were continuously enrolled into the study group according to the surgery schedule of the Lively Eye Clinic. Fifty-seven patients ( 23 males, age range: $60-84$ years; 34 females, age range: $62-83$ years) were included in the study group. After the study group recruiting period, the control group was continuously enrolled from among patients who had the same surgical procedure with the same IOLs, according to the surgery schedule of the Lively Eye Clinic. Twenty patients (10 males, age range: $58-80$ years; 10 females, age range: $60-85$ years) were included in the control group. No patients in either group subsequently declined to participate in this study.

\section{Measurements and Study Protocol}

MPOD was measured with heterochromatic flicker photometry as the differences between sensitivities at $465 \mathrm{~nm}$ and $530 \mathrm{~nm}$ (MPSII; Elektron Technology, Switzerland). One week after cataract surgery, the baseline MPOD was measured in both the study and control groups. Three tablets (the recommended daily 
Table 2. Characteristics of the study and control groups

\begin{tabular}{|c|c|c|}
\hline & The study group & The control group \\
\hline \multicolumn{3}{|l|}{ Males } \\
\hline$N$ & 23 & 10 \\
\hline \multicolumn{3}{|l|}{ Age, y/o } \\
\hline Mean \pm SD (range) & $72.9 \pm 7.4(60-84)$ & $69.3 \pm 9.2(58-80)$ \\
\hline \multicolumn{3}{|l|}{ MPOD at baseline } \\
\hline Mean \pm SD (range) & $0.54 \pm 0.19(0.23-0.86)$ & $0.53 \pm 0.19(0.29-0.86)$ \\
\hline \multicolumn{3}{|l|}{ Females } \\
\hline$N$ & 34 & 10 \\
\hline \multicolumn{3}{|l|}{ Age, y/o } \\
\hline Mean \pm SD (range) & $71.2 \pm 5.2(62-83)$ & $71.0 \pm 3.7(60-85)$ \\
\hline \multicolumn{3}{|l|}{ MPOD at baseline } \\
\hline Mean \pm SD (range) & $0.6 \pm 0.2(0.24-0.9)$ & $0.59 \pm 0.29(0.24-0.91)$ \\
\hline
\end{tabular}

Fig. 1. Changes in MPOD. Compared with baseline, MPOD significantly increased after 1 week of lutein supplementation and remained elevated for 2 weeks after the end of supplementation in both males and females. There were no differences in the MPOD between genders at baseline and after 2 weeks of supplementation. However, compared with the MPOD in males, the MPOD in females was significantly higher after 3 weeks of supplementation and remained higher until 2 weeks after the end of supplementation (analysis of variance, $\left.{ }^{*} p<0.01\right)$. MPOD, macular pigment optical density.

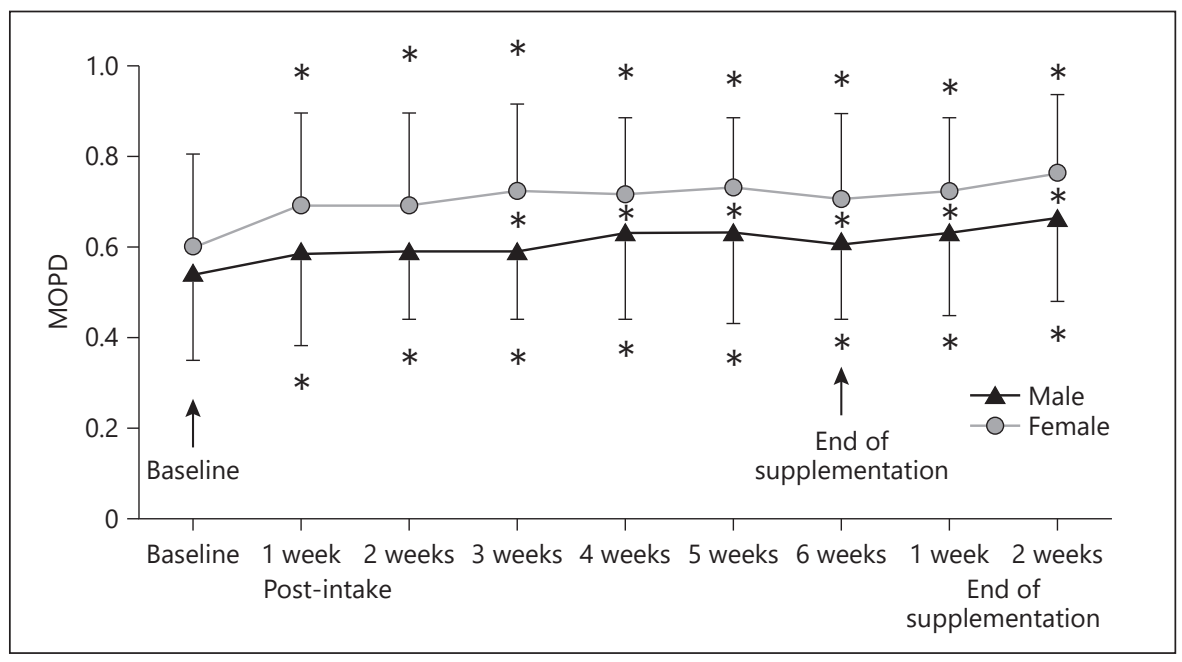

dosage) of Ocuvite + Lutein ${ }^{\circledR}$ (Bausch + Lomb, Rochester, NY, USA), a lutein-containing antioxidant supplement with components similar to the AREDS formula which has been proven effective on preventing the progression of AMD [40], were administered orally each day, beginning the day after the first measurement in the study group. The composition of the Ocuvite + Lutein ${ }^{\circledR}$ supplement is described in Table 1 . During the 6-week supplementation period, the MPOD was measured each week. Measurements continued 2 weeks after the end of supplementation in the study group. In the control group, MPOD was measured at baseline, 1 week after cataract surgery, and each subsequent week for 4 weeks.

Rates of increase were defined as increases in MPOD measured at the end of each week, compared with measurement at baseline. Statistical analyses of the changes in MPOD were performed by using analysis of variance. Comparisons were analyzed by using the Mann-Whitney U test. Correlations were analyzed by using Spearman's rank correlation coefficient. Significant differences were regarded as those where $p<0.05$.

\section{Results}

There was no significant difference in age between genders $($ mean $\pm \mathrm{SD})$ : males $=72.9 \pm 7.4$ years, while females $=71.2 \pm 5.2$ years in the control group. The age distribution of the control group was not different from the study group: males $=69.3 \pm 9.2$ years and females $=$ $71.0 \pm 3.7$ years. The MPOD at baseline was no different between the study group and the control group, either (Table 2).

In the control group, the MPOD was significantly increased after 1 week of supplementation (males: $0.59 \pm$ 0.21; females: $0.69 \pm 0.2$ ), compared with baseline (males: $0.54 \pm 0.19$; females: $0.6 \pm 0.2$ ), and remained elevated for 2 weeks after the end of supplementation in both genders (males: $0.66 \pm 0.18$; females: $0.76 \pm 0.17$ ) (shown in Fig. 1, 


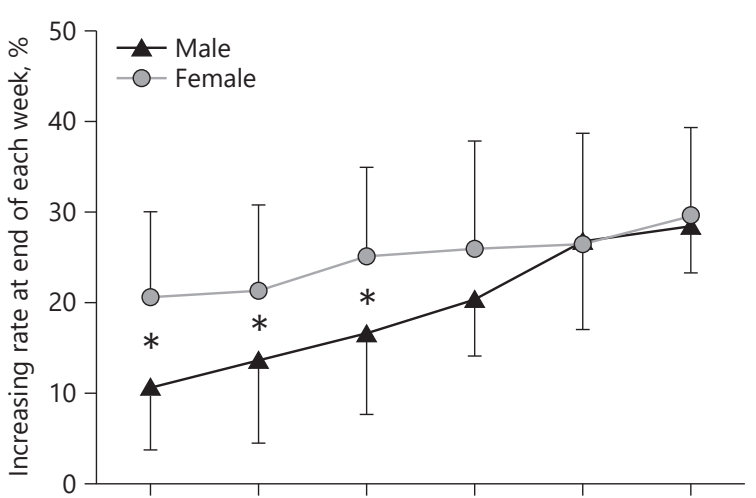

Post-intake 1 week 2 weeks 3 weeks 4 weeks 5 weeks 6 weeks

Fig. 2. Increasing rates of MPOD at the end of each week. There were no changes in the rates of MPOD increase during supplementation in either males or females. Compared with the rates of MPOD increase in males, the rates in females were significantly higher during the first 3 weeks of supplementation (Mann-Whitney U test, $\left.{ }^{*} p<0.05\right)$. MPOD, macular pigment optical density.

$p<0.01)$. There were no differences in the MPOD between genders at baseline and after 2 weeks of supplementation. However, compared with the MPOD in males, the MPOD in females was significantly higher after 3 weeks of supplementation and remained higher until 2 weeks after the end of supplementation $(p<0.05)$. The rates of MPOD increase at the end of 6 weeks of supplementation were $28.6 \pm 23.75 \%$ in males and $29.8 \pm 26.6 \%$ in females (shown in Fig. 2). Compared with the rates of increase in males, the rates of MPOD increase were significantly higher in females for the first 3 weeks $(p<0.05)$. However, there were no significant differences between genders after 4 weeks of supplementation.

In both genders, the levels of MPOD at the end of 6-week supplementation were significantly correlated with the levels of MPOD at baseline in both genders (shown in Fig. 3). However, the rates of MPOD increase at the end of 6 weeks of supplementation were negatively correlated with the levels of MPOD at baseline (shown in Fig. 4). Considering the differences in rates of MPOD increase with respect to baseline, the rates of MPOD increase at the end of 6 weeks of supplementation were significantly higher in patients with the lowest quintile baseline MPOD than in those with the highest quintile baseline MPOD (shown in Fig. 5, $p<0.05$ ). Although it did not reach statistical significance, among patients with the lowest quintile baseline MPOD, the rate of MPOD in-

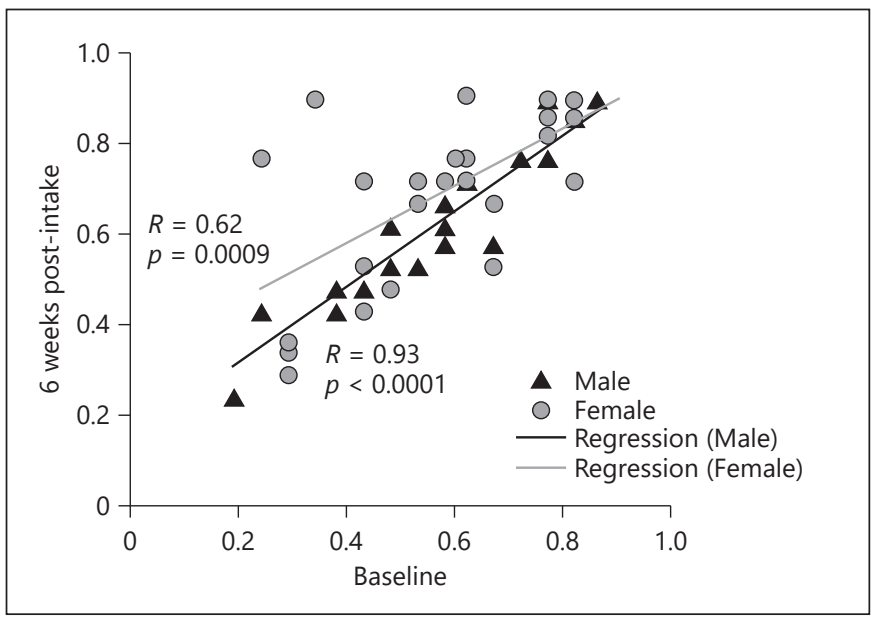

Fig. 3. The correlation between MPOD at baseline and after 6 weeks of supplementation. There were positive correlations between MPOD at baseline and after 6 weeks of supplementation in both genders. The correlations were analyzed by using Spearman's rank correlation coefficient, while the regression lines were added to show the direction of correlation. MPOD, macular pigment optical density.

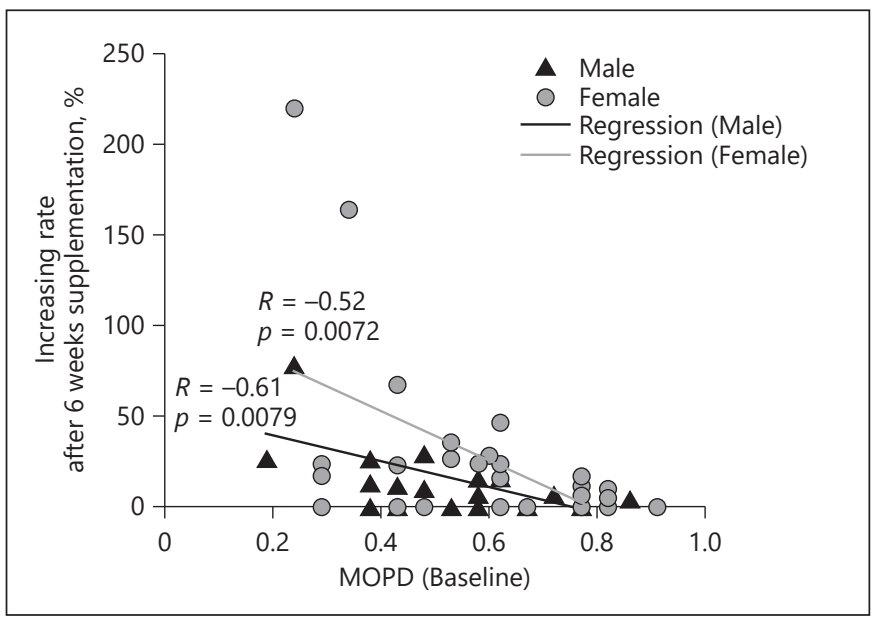

Fig. 4. The correlation between MPOD at baseline and the increasing rates after 6 weeks of supplementation. After 6 weeks of supplementation, the rates of MPOD increase were negatively correlated with baseline MPOD in both genders. The correlations were analyzed by using Spearman's rank correlation coefficient, while the regression lines were added to show the direction of correlation. MPOD, macular pigment optical density.

crease tended to be higher in females than in males. Among the control group, the MPOD did not change 1 week later (males: $0.53 \pm 0.19$; females: $0.59 \pm 0.29$ ) compared with baseline (males: $0.55 \pm 0.19$; females: $0.59 \pm$ 


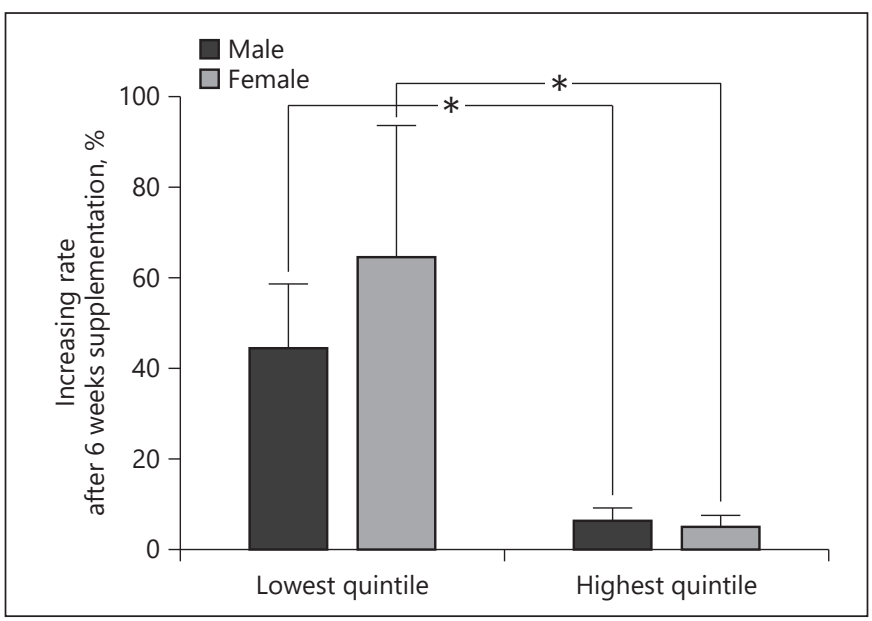

Fig. 5. The comparisons between patients who had the highest quintile and those who had the lowest quintile MPOD at baseline. Compared with patients who had the highest quintile MPOD at baseline, MPOD significantly increased after 6 weeks of supplementation in those who had the lowest quintile MPOD at baseline $\left({ }^{*} p<0.05\right)$. MPOD, macular pigment optical density.

0.24). The MPOD remained at the same levels 4 weeks after in the control group (males: $0.54 \pm 0.23$; females: $0.58 \pm 0.24$ ) (shown in Fig. 6).

\section{Discussion}

During 6 weeks of lutein supplementation, MPOD increased at the end of the first week in patients who had undergone cataract surgery; this increase persisted until 2 weeks after the end of supplementation. Notably, the increase was greater in females. In addition, the increases were inversely proportional to the baseline MPOD, which indicated that patients with lower MPOD at baseline exhibited a greater increase in MPOD than patients with a higher MPOD at baseline. However, MPOD of the control group kept the same levels through the 4-week measurement period.

The results of our previous study indicated the increasing levels of lutein in serum after 6-week intake of the same supplement [41]. After oral consumption, serum lutein concentrations rapidly reach a peak, within $16 \mathrm{~h} \mathrm{[42].}$ During continuous lutein administration, the serum levels increase and reach a plateau within the first 2 weeks [43]. Those prior findings are consistent with the early increase of MPOD observed in the present study. The process by which carotenoids and their degradation

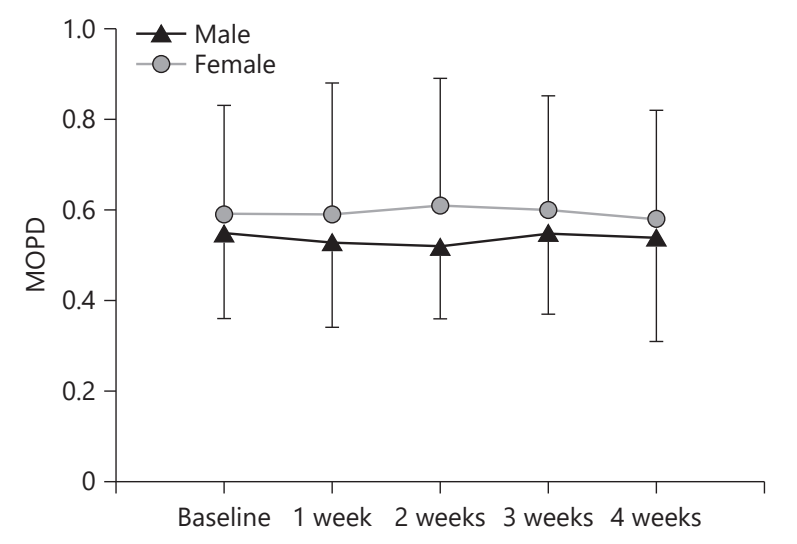

Fig. 6. The measurements of MPOD among the control group. Among the control group, there were no statistical differences in age between genders. Compared with baseline, the MPOD did not change 1 week later and remained at the same level 4 weeks later. MPOD, macular pigment optical density.

products are removed from the retina is unclear. However, macular carotenoid levels are known to be remarkably stable. Slow turnover and maintenance of MP have been reported following long periods of supplementation with lutein [44]. The present study also revealed that MPOD remained stable over 2 weeks after the end of supplementation, consistent with the results of a previous study [45].

At baseline, there were no gender differences in MPOD. However, with a fixed dose of supplementation, the increase in MPOD was greater in females than in males. The mechanisms involved in gender differences in the increase of MPOD are unclear. Hormonal influences may induce gender differences in the behavior of proteins involved in the absorption and transportation of lutein and zeaxanthin. Several highly selective transport proteins are involved in the specific selection of lutein and zeaxanthin for incorporation in the retina and other ocular tissue [46]. Dietary carotenoids are released from food matrices through the action of esterases, cleaved by carotenoid cleavage enzymes, and solubilized into micelles [47]. A cell surface glycoprotein, scavenger receptor class $B$, located on intestinal mucosal cells, then facilitates uptake and transport of carotenoids to the portal circulation in the chylomicron fraction $[48,49]$. Carotenoids are then secreted into the lymphatic and portal circulation for transport to the liver. Carotenoids are modified in the 
liver before release into the bloodstream [50, 51]. Most hydrophobic carotenoids, such as lycopene and beta-carotene, are transported on low-density lipoprotein, whereas the more hydrophilic lutein and zeaxanthin are carried by high-density lipoprotein (HDL) [52]. The scavenger receptor class B facilitates uptake of lutein, zeaxanthin, and other carotenoids into retinal and intestinal cells [53]. Lutein and zeaxanthin are specifically uptaken by selective binding proteins on retinal pigment epithelial cells, such as glutathione S-transferase P1 [54] and steroidogenic acute regulatory domain protein 3 [55]. Individual differences with respect to increases in MPOD after supplementation may result from variations in proteins involved in the absorption and transportation of lutein.

Gender differences have been also reported with respect to the transport proteins described above. Females reportedly exhibit a less atherogenic lipid profile than males due to higher levels of HDL [56-58], which carries lutein and zeaxanthin to the retina. Serum HDL is significantly associated with serum lutein/zeaxanthin and MPOD [59]. Reportedly, estrogen affects plasma lipoprotein metabolism [60, 61]; this may affect carotenoid availability because of the role of lipoprotein in carotenoid transport. Gender differences in MPOD may thus be due to the hormonal influence on absorption and transportation of carotenoids. Although plasma concentrations of lutein and zeaxanthin were positively correlated with MPOD in both genders, dietary fat was correlated with MPOD in a disparate manner between genders: positively in males and negatively in females [62]. Additionally, adipose tissue lutein concentration was significantly negatively correlated with MPOD in females, but significantly positively correlated in males [63]. These gender-related differences suggest that lutein and zeaxanthin are dynamic tissue components and that lutein metabolism may differ between genders.

The preservation of visual sensitivity has been associated with higher MP density in patients over 60 years of age [64]. Obana and coworkers [65] reported that MPOD levels decline by $>10 \%$ with every 10 -year increase in age. A reduction in MPOD after cataract surgery was also reported $[29,66]$. Among elderly patients over 60 years of age in the present study, 6 weeks of lutein supplementation induced an increase in MPOD of nearly 30\%; these increases were more significant in patients with lower baseline MPOD. These findings suggest that lutein supplementation may increase MPOD, thereby counteracting the aging-related decrease in MPOD and protecting photoreceptors; this may improve visual sensitivity in el-

MPOD in Pseudophakia after Lutein Supplementation derly individuals, especially those with lower MPOD and those who have undergone cataract surgery. Lutein supplementation may further prevent the onset and progression of AMD in those patients.

It has been reported that the individual intake of lutein might not be sufficient to increase the MPOD levels [67]. The supplement used in this study also included vitamin $\mathrm{C}$ (Vit C), vitamin E (Vit E), $\beta$-carotene, selenium (Se), and Zinc (Zn). Several investigations have demonstrated the protective effects of $\mathrm{Vit} \mathrm{C}$, $\mathrm{Vit} \mathrm{E}$, and $\mathrm{Zn}$ against the risk of AMD [68-70]. In addition, the Age-Related Eye Disease Study Research Group reported reduced development of advanced AMD among patients who received Vit $\mathrm{C}$ and Vit E plus Zn [71, 72]. The combination of Vit $\mathrm{E}, \mathrm{Vit} \mathrm{C}$, and Se has been also reported to reduce the risk of AMD, although no significant protective effects were found with respect to separate supplementation with each individual component [73]. Lutein and zeaxanthin supplements alone did not influence AMD progression over 3 years [74], although lutein and zeaxanthin supplements did influence this progression when used in combination with other antioxidant supplements $[75,76]$. The increases in MPOD observed in this study may thus be due to the synergistic effects of Vit E, Vit C, Zn, Se, and lutein included in the supplement used in this study.

In addition to dietary and supplement intake, several factors may influence MPOD; these include genotype [77], lifestyle characteristics (e.g., increased body fat [78, 79]), and sunlight exposure [80-82]. An important limitation of this study is that those factors were not evaluated. However, the following potential confounders were considered. With respect to metabolic health status, no patients with systemic diseases (e.g., diabetes) were included. Concerning nutritional status, questionnaires regarding dietary details were administered at baseline and 2 weeks later; there were no remarkable changes in either group. Because both study and control groups were continuously enrolled according to the surgery schedule, it is unlikely that patients in the study group had different nutritional awareness, compared with patients in the control group. Although we did not extensively investigate lifestyle factors, phenotypes, and sunlight exposure that could also influence MPOD, it is unlikely that those factors considerably differed between patients in the study and control groups because both groups were continuously enrolled according to the surgery schedule. Furthermore, there were no differences in baseline MPOD between the study and control groups.

MPOD can also be measured with physical techniques, such as fundus reflectometry [83] and autofluorescence 
[84]. Although these methods may be more objective, they require expensive equipment and time-consuming procedures that are difficult for both the examiner and examinee. To the best of our knowledge, no reference method has been established for MP quantification [85, 86]. In this study, the MPOD was measured with heterochromatic flicker photometry, which is a psychophysical method broadly used for MPOD assessment [87, 88]. However, heterochromatic flicker photometry has several limitations, mainly with respect to patient compliance and usage in patients with low visual acuity. Nonetheless, it is rapid and easy to use. Strong correlations with the objective measurements obtained using fundus reflectometry [89] indicate that heterochromatic flicker photometry results are reliable.

\section{Conclusions}

MPOD increased after lutein supplementation in pseudophakic patients. Lutein supplementation is presumed to increase MPOD and could delay the onset of AMD after cataract surgery, especially in patients with lower MPOD. With a fixed amount of lutein supplementation, MPOD increased more in females than in males. These findings suggest that there are gender differences in absorption and transportation of carotenoids, which need further investigation.

\section{Statement of Ethics}

Informed consent was obtained from all patients for inclusion before they participated in the study, and the study was performed in accordance with the tenets of the Declaration of Helsinki. Approval was granted by the Human Experimentation Committee of the Saitama Medical Center in Dokkyo Medical University (Dokkyo Ikadaigaku Saitama Iryousenta Seimei Rinri Iinkai) (No. 22025).

\section{Conflict of Interest Statement}

The authors have no conflicts of interest to declare.

\section{Funding Sources}

No funding is in the manuscript.

\section{Author Contributions}

R.H. and S.H. conceived, designed, and performed the experiments; R.H. analyzed the data; S.H. contributed to materials and analysis tools; R.H. and S.M. wrote the manuscript. All authors read and approved the final manuscript.

\section{Data Availability Statement}

The datasets used and/or analyzed during the current study are available from the corresponding author on reasonable request.

\section{References}

1 Krinsky NI, Landrum JT, Bone RA. Biologic mechanisms of the protective role of lutein and zeaxanthin in the eye. Annu Rev Nutr. 2003;23:171-201.

2 Krinsky NI, Johnson EJ. Carotenoid actions and their relation to health and disease. $\mathrm{Mol}$ Aspects Med. 2005;26(6):459-516.

3 Li SY, Lo AC. Lutein protects RGC-5 cells against hypoxia and oxidative stress. Int $\mathrm{J} \mathrm{Mol}$ Sci. 2010;11(5):2109-17.

4 Sasaki M, Ozawa Y, Kurihara T, Noda K, Imamura Y, Kobayashi S, et al. Neuroprotective effect of an antioxidant, lutein, during retinal inflammation. Invest Ophthalmol Vis Sci. 2009;50(3):1433-9.

5 Izumi-Nagai K, Nagai N, Ohgami K, Satofuka S, Ozawa Y, Tsubota K, et al. Macular pigment lutein is antiinflammatory in preventing choroidal neovascularization. Arterioscler Thromb Vasc Biol. 2007;27(12):2555-62.

6 Bian Q, Qin T, Ren Z, Wu D, Shang F. Lutein or zeaxanthin supplementation suppresses inflammatory responses in retinal pigment epithelial cells and macrophages. Adv Exp Med Biol. 2012;723:43-50.
7 Bhosale P, Serban B, Bernstein PS. Retinal carotenoids can attenuate formation of $\mathrm{A} 2 \mathrm{E}$ in the retinal pigment epithelium. Arch Biochem Biophys. 2009;483(2):175-81.

8 Sundelin SP, Nilsson SE. Lipofuscin-formation in retinal pigment epithelial cells is reduced by antioxidants. Free Radic Biol Med. 2001;31(2):217-25.

9 Winkler BS, Boulton ME, Gottsch JD, Sternberg P. Oxidative damage and age-related macular degeneration. Mol Vis. 1999;5:32.

10 Bone RA, Landrum JT, Mayne ST, Gomez CM, Tibor SE, Twaroska EE. Macular pigment in donor eyes with and without AMD: a case-control study. Invest Ophthalmol Vis Sci. 2001;42(1):235-40.

$11 \mathrm{Wu}$ J, Cho E, Willett WC, Sastry SM, Schaumberg DA. Intakes of lutein, zeaxanthin, and other carotenoids and age-related macular degeneration during 2 decades of prospective followup. JAMA Ophthalmol. 2015;133(12):1415-24.

12 Haegerstrom-Portnoy G. Short-wavelengthsensitive-cone sensitivity loss with aging: a protective role for macular pigment? J Opt Soc Am A. 1988;5(12):2140-4.
13 Landrum JT, Bone RA, Joa H, Kilburn MD, Moore LL, Sprague KE. A one year study of the macular pigment: the effect of 140 days of a lutein supplement. Exp Eye Res. 1997;65(1): 57-62.

14 Weiter JJ, Delori F, Dorey CK. Central sparing in annular macular degeneration. Am J Ophthalmol. 1988;106(3):286-92.

15 Barker FM 2nd, Snodderly DM, Johnson EJ, Schalch W, Koepcke W, Gerss J, et al. Nutritional manipulation of primate retinas, $\mathrm{V}$ : effects of lutein, zeaxanthin, and n-3 fatty acids on retinal sensitivity to blue-light-induced damage. Investig Ophthalmol Vis Sci. 2011; 52:3934-42.

16 Bian Q, Gao S, Zhou J, Qin J, Taylor A, Johnson EJ, et al. Lutein and zeaxanthin supplementation reduces photooxidative damage and modulates the expression of inflammation-related genes in retinal pigment epithelial cells. Free Radic Biol Med. 2012;53(6): 1298-307. 
17 Nolan JM, Stack J, O’Donovan O, Loane E, Beatty S. Risk factors for age-related maculopathy are associated with a relative lack of macular pigment. Exp Eye Res. 2007;84(1): 61-74.

18 Beatty S, Murray IJ, Henson DB, Carden D, Koh H, Boulton ME. Macular pigment and risk for age-related macular degeneration in subjects from a Northern European population. Invest Ophthalmol Vis Sci. 2001;42(2): 439-46.

19 Bernstein PS, Zhao D-Y, Wintch SW, Ermakov IV, McClane RW, Gellermann W. Resonance Raman measurement of macular carotenoids in normal subjects and in age-related macular degeneration patients. Ophthalmology. 2002;109(10):1780-7.

20 Kaya S, Weigert G, Pemp B, Sacu S, Werkmeister RM, Dragostinoff N, et al. Comparison of macular pigment in patients with agerelated macular degeneration and healthy control subjects - a study using spectral fundus reflectance. Acta Ophthalmol. 2012; 90(5):e399-403.

21 Granado F, Olmedilla B, Blanco I. Nutritional and clinical relevance of lutein in human health. Br J Nutr. 2003;90(3):487-502.

22 Burke JD, Curran-Celentano J, Wenzel AJ. Diet and serum carotenoid concentrations affect macular pigment optical density in adults 45 years and older. J Nutr. 2005;135(5):120814.

23 Mares J, LaRowe TL, Snodderly DM, Moeller SM, Gruber MJ, Klein ML, et al. CAREDS Macular Pigment Study Group and Investigations. Predictors of optical density of lutein and zeaxanthin in retinas of older women in the carotenoids in age-related eye diseases study, an ancillary study of the Women's Health Initiative. Am J Clin Nutr. 2006;84 1107-22.

24 Mares JA, LaRowe TL, Snodderly DM, Moeller SM, Gruber MJ, Klein ML, et al. Predictors of optical density of lutein and zeaxanthin in retinas of older women in the Carotenoids in Age-Related Eye Disease Study, an ancillary study of the Women's Health Initiative. Am J Clin Nutr. 2006;84(5):1107-22.

25 Obana A, Tanito M, Gohto Y, Okazaki S, Gellermann W, Bernstein PS. Changes in macular pigment optical density and serum lutein concentration in Japanese subjects taking two different lutein supplements. PLoS One. 2015 10(10): 0139257.

26 Lerman S. Ultraviolet radiation protection. CLAO J. 1985;11:9-45.

27 Matsushima H, Matsui E. Blue-light filtering intraocular lens. Jpn J Refract Surg. 2005;19: 275-9.

28 King A, Gottlieb E, Brooks DG, Murphy MP, Dunaief JL. Mitochondria-derived reactive oxygen species mediate blue light-induced death of retinal pigment epithelial cells. Photochem Photobiol. 2004;79(5):470-5.

29 Obana A, Tanito M, Gohto Y, Gellermann W, Okazaki S, Ohira A. Macular pigment changes in pseudophakic eyes quantified with reso- nance Raman spectroscopy. Ophthalmology. 2011;118(9):1852-8.

30 Verdina T, Date P, Benatti C, Lazzerini A, Fornasari E, De Maria M, et al. Evaluation of macular pigment optical density following femtosecond laser-assisted cataract surgery. Clin Ophthalmol. 2019;13:821-8.

31 Demirel S, Bilici S, Batıolu F, Ozmert E. The effect of age and cataract surgery on macular pigment optic density: a cross-sectional, comparative study. Graefes Arch Clin Exp Ophthalmol. 2014;252(2):213-8.

32 Cugati S, Mitchell P, Rochtchina E, Tan AG, Smith W, Wang JJ. Cataract surgery and 10year incidence of age-related maculopathy: the Blue Mountains Eye Study. Ophthalmology. 2006;113:2020-5.

33 Klein R, Klein B, Wong TY, Tomany SC, Cruickshanks KJ. The association of cataract surgery with the long-term incidence of agerelated maculopathy: the Beaver Dam eye study. Arch Ophthalmol. 2002;120:1551-8.

34 Nolan JM, O’Reilly P, Loughman J, Stack J, Loane E, Connolly E, et al. Augmentation of macular pigment following implantation of blue light-filtering intraocular lenses at the time of cataract surgery. Invest Ophthalmol Vis Sci. 2009;50(10):4777-85.

35 Brockmann C, Schulz M, Laube T. Transmittance characteristics of ultraviolet and bluelight-filtering intraocular lenses. J Cataract Refract Surg. 2008;34(7):1161-6.

36 Mainster MA. Violet and blue light blocking intraocular lenses: photoprotection versus photoreception. Br J Ophthalmol. 2006;90(6): 784-92.

37 Downie LE, Busija L, Keller PR. Blue-light filtering intraocular lenses (IOLs) for protecting macular health. Cochrane Database Syst Rev. 2018;22(5):CD011977.

38 Nagai N, Izumi-Nagai K, Suzuki M, Shinoda $\mathrm{H}$, Koto T, Uchida A, et al. Association of macular pigment optical density with serum concentration of oxidized low-density lipoprotein in healthy adults. Retina. 2015;35(4): 820-6.

39 Beatty S, Nolan J, Kavanagh H, O’Donovan O. Macular pigment optical density and its relationship with serum and dietary levels of lutein and zeaxanthin. Arch Biochem Biophys. 2004;430(1):70-6.

40 Age-Related Eye Disease Study 2 Research Group. Lutein + zeaxanthin and omega- 3 fatty acids for age-related macular degeneration: the Age-Related Eye Disease Study 2 (AREDS2) randomized clinical trial Age-Related Eye Disease Study 2 Research Group. JAMA. 2013;309:2005-15.

41 Hayashi R. The potential effects of a luteincontaining supplement on inhibiting the pregression of cataracts: the changes of antioxidant-related proteins in aqueous humor and lenticular anterior capsule of patients with cataract. J Jap Soc Cataract Res. 2018;30:1321.

42 Kostic D, White WS, Olson JA. Intestinal absorption, serum clearance, and interactions between lutein and beta-carotene when administered to human adults in separate or combined oral doses. Am J Clin Nutr. 1995; 62(3):604-10.

43 Bone RA, Landrum JT. Dose-dependent response of serum lutein and macular pigment optical density to supplementation with lutein esters. Arch Biochem Biophys. 2010; 504(1):50-5.

44 Bone RA, Landrum JT, Guerra LH, Ruiz CA Lutein and zeaxanthin dietary supplements raise macular pigment density and serum concentrations of these carotenoids in humans. J Nutr. 2003;133(4):992-8.

45 Johnson EJ, Hammond BR, Yeum KJ, Qin J, Wang XD, Castaneda C, et al. Relation among serum and tissue concentrations of lutein and zeaxanthin and macular pigment density. Am J Clin Nutr. 2000;71(6):1555-62.

46 Bersnstein P, Khachik F, Carvalh L, Muir G, Zhao D, Katz N. Identification and quantitation of carotenoids and their metabolites in the tissues of the human eye. Exp Eye Res. 2001;72:215-23.

47 Erdman JW, Bierer TL, Gugger ET. Absorption and transport of carotenoids. Ann N Y Acad Sci. 1993;691:76-85.

48 Goti D, Reicher H, Malle E, Kostner GM, Panzenboeck U, Sattler W. High-density lipoprotein (HDL3)-associated -tocopherol is taken up by HepG2 cells via the selective uptake pathway and resecreted with endogenously synthesized apo-lipoprotein B-rich lipoprotein particles. Biochem J. 1998;332:57-65.

49 Rigotti A, Krieger M. Getting a handle on "good" cholesterol with the high-density lipoprotein receptor. N Engl J Med. 1999;341(26): 2011-3.

50 Thomson LR, Toyoda Y, Langner A, Delori FC, Garnett KM, Craft N, et al. Elevated retinal zeaxanthin and prevention of light-induced photoreceptor cell death in quail. Invest Ophthalmol Vis Sci. 2002;43(11):353849.

51 Toyoda Y, Thomson LR, Langner A, Craft NE, Garnett KM, Nichols CR, et al. Effect of dietary zeaxanthin on tissue distribution of zeaxanthin and lutein in quail. Invest Ophthalmol Vis Sci. 2002;43(4):1210-21.

52 Connor WE, Duell PB, Kean R, Wang Y, Wang Y. The prime role of HDL to transport lutein into the retina: evidence from HDLdeficient WHAN chicks having a mutant ABCA1 transporter. Invest Ophthalmol Vis Sci. 2007;24:4226-31.

53 During A, Doraiswamy S, Harrison EH. Xanthophylls are preferentially taken up compared with beta-carotene by retinal cells via a SRBI-dependent mechanism. J Lipid Res. 2008;49(8):1715-24.

54 Bhosale P, Larson AJ, Frederick JM, Southwick K, Thulin CD, Bernstein PS. Identification and characterization of a $\mathrm{Pi}$ isoform of glutathione S-transferase (GSTP1) as a zeaxanthin-binding protein in the macula of the human eye. J Biol Chem. 2004;279(47): 49447-54. 
55 Li B, Vachali P, Bernstein PS. Human ocular carotenoid-binding proteins. Photochem Photobiol Sci. 2010;9(11):1418-25.

56 Carlson LA, Ericsson M. Quantitative and qualitative serum lipoprotein analysis. Part 2. Studies in male survivors of myocardial infarction. Atherosclerosis. 1975 May-Jun; 21(3):435-50

57 Kolovou GD, Anagnostopoulou KK, Damaskos DS, Bilianou HI, Mihas C, Milionis HJ, et al. Gender differences in the lipid profile of dyslipidemic subjects. Eur J Intern Med. 2009; 20(2):145-51.

58 Anagnostis P, Stevenson JC, Crook D, Johnston DG, Godsland IF. Effects of menopause, gender and age on lipids and high-density lipoprotein cholesterol subfractions. Maturitas. 2015;81(1):62-8.

59 Renzi LM, Hammond BR Jr, Dengler M, Roberts $\mathrm{R}$. The relation between serum lipids and lutein and zeaxanthin in the serum and retina: results from cross-sectional, case-control and case study designs. Lipids Health Dis. 2012; 11:33.

60 Schaefer EJ, Foster DM, Zech LA, Lindgren FT, Brewer HB Jr, Levy RI. The effects of estrogen administration on plasma lipoprotein metabolism in premenopausal females. J Clin Endocrinol Metab. 1983;57(2):262-7.

61 Basdevant A. Steroids and lipid metabolism: mechanisms of action. Int J Fertil. 1992;37: 93-7.

62 Hammond BR Jr, Curran-Celentano J, Judd S, Fuld K, Krinsky NI, Wooten BR, et al. Sex differences in macular pigment optical density: relation to plasma carotenoid concentrations and dietary patterns. Vision Res. 1996;36(13): 2001-12.

63 Johnson EJ, Hammond BR, Yeum KJ, Qin J, Wang XD, Castaneda C, et al. Relation among serum and tissue concentrations of lutein and zeaxanthin and macular pigment density. Am J Clin Nutr. 2000;71(6):1555-62.

64 Hammond BR Jr, Wooten BR, Snodderly DM. Preservation of visual sensitivity of older subjects: association with macular pigment density. Invest Ophthalmol Vis Sci. 1998; 39(2):397-406.

65 Obana A, Gohto Y, Tanito M, Okazaki S, Gellermann W, Bernstein PS, et al. Effect of age and other factors on macular pigment optical density measured with resonance Raman spectroscopy. Graefes Arch Clin Exp Ophthalmol. 2014;252(8):1221-8.

66 Demirel S, Bilici S, Batıolu F, Ozmert E. The effect of age and cataract surgery on macular pigment optic density: a cross-sectional, comparative study. Graefes Arch Clin Exp Ophthalmol. 2014;252(2):213-8.
67 Sasamoto Y, Gomi F, Sawa M, Tsujikawa M, Nishida K. Effect of 1-year lutein supplementation on macular pigment optical density and visual function. Graefes Arch Clin Exp Ophthalmol. 2011;249(12):1847-54.

68 Gopinath B, Liew G, Russell J, Cosatto V, Burlutsky G, Mitchell P. Intake of key micronutrients and food groups in patients with latestage age-related macular degeneration compared with age-sex-matched controls. $\mathrm{Br} \mathrm{J}$ Ophthalmol. 2017;101(8):1027-31.

69 Tan JS, Wang JJ, Flood V, Rochtchina E, Smith W, Mitchell P. Dietary antioxidants and the long-term incidence of age-related macular degeneration: the Blue Mountains Eye Study. Ophthalmology. 2008;115(2):33441.

70 van Leeuwen R, Boekhoorn S, Vingerling JR, Witteman JC, Klaver CC, Hofman A, et al. Dietary intake of antioxidants and risk of agerelated macular degeneration. JAMA. 2005; 294(24):3101-7.

71 Age-Related Eye Disease Study Research Group. A randomized, placebo-controlled, clinical trial of high-dose supplementation with vitamins $\mathrm{C}$ and $\mathrm{E}$, beta carotene, and zinc for age-related macular degeneration and vision loss: AREDS report no. 8. Arch Ophthalmol. 2001;119:1417-36.

72 Chew EY, Clemons TE, Agrón E, Sperduto RD, Sangiovanni JP, Kurinij N, et al. Age-Related Eye Disease Study Research Group. Long-term effects of vitamins $\mathrm{C}$ and $\mathrm{E}$, $\beta$-carotene, and zinc on age-related macular degeneration: AREDS report no. 35. Ophthalmology. 2013;120:1604-11.

73 Eye Disease Case-Control Study Group. Antioxidant status and neovascular age-related macular degeneration. Eye Disease CaseControl Study Group. Arch Ophthalmol. 1993;111(1):104-9.

74 Akuffo KO, Nolan JM, Howard AN, Moran R, Stack J, Klein R, et al. Sustained supplementation and monitored response with differing carotenoid formulations in early age-related macular degeneration. Eye (Lond). 2015; 29(7):902-12.

75 Beatty S, Chakravarthy U, Nolan JM, Muldrew KA, Woodside JV, Denny F, et al. Secondary outcomes in a clinical trial of carotenoids with coantioxidants versus placebo in early age-related macular degeneration. Ophthalmology. 2013;120(3):600-6

76 Age-Related Eye Disease Study 2 (AREDS2) Research Group; Chew EY, Chew EY, Clemons TE, Sangiovanni JP, Danis RP 3rd, Ferris FL, et al. Secondary analyses of the effects of lutein/zeaxanthin on age-related macular degeneration progression: AREDS2 report No. 3. JAMA Ophthalmol. 2014;132(2):142-9.
77 Liew SM, Gilbert CE, Spector TD, Beatty S, van Kuijk FJ, Mellerio J, et al. Macular pigment heritability: a twin study. Invest Ophthalmol Vis Sci. 2005;46:4430-6.

78 Hammond BR Jr, Ciulla TA, Snodderly DM. Macular pigment density is reduced in obese subjects. Invest Ophthalmol Vis Sci. 2002 43(1):47-50.

79 Nolan J, O’Donovan O, Kavanagh H, StackHarrison JM, Harrison M, Muldoon A, et al. Macular pigment and percentage of body fat. Invest Ophthalmol Vis Sci. 2004;45(11): 3940-50.

80 West SK, Rosenthal FS, Bressler NM, Bressler SB, Munoz B, Fine SL, et al. Exposure to sunlight and other risk factors for age-related macular degeneration. Arch Ophthalmol. 1989;107(6):875-9.

81 Taylor HR, West S, Muñoz B, Rosenthal FS, Bressler SB, Bressler NM. The long-term effects of visible light on the eye. Arch Ophthalmol. 1992;110(1):99-104.

82 Darzins P, Mitchell P, Heller RF. Sun exposure and age-related macular degeneration: an Australian case-control study. Ophthalmology. 1997;104:770-6.

83 Berendschot TTJM, van Norren D. On the age dependency of the macular pigment optical density. Exp Eye Res. 2005;81(5):602-9.

84 Delori FC. Autofluorescence method to measure macular pigment optical densities fluorometry and autofluorescence imaging. Arch Biochem Biophys. 2004;430(2):156-62.

85 Hammond BR Jr, Wooten BR, Smollon B. Assessment of the validity of in vivo methods of measuring human macular pigment optical density. Optom Vis Sci. 2005;82(5):387-404.

86 Beatty S, van Kuijk FJ, Chakravarthy U. Macular pigment and age-related macular degeneration: longitudinal data and better techniques of measurement are needed. Invest Ophthalmol Vis Sci. 2008;49(3):843-5.

87 Wooten BR, Hammond BR Jr, Land RI, Snodderly DM. A practical method for measuring macular pigment optical density. Invest Ophthalmol Vis Sci. 1999;40(11):2481-9.

88 LaRowe TL, Mares JA, Snodderly DM, Klein ML. Macular pigment density and age-related maculopathy in the carotenoids in age-related eye disease study. An ancillary study of the Women's Health Initiative. Ophthalmology. 2008;115:876-83.

89 van der Veen RL, Berendschot TT, Makridaki M, Hendrikse F, Carden D, Murray IJ. Correspondence between retinal reflectometry and a flicker-based technique in the measurement of macular pigment spatial profiles. Biomed Opt. 2009 Nov-Dec;14(6):064046. 